\title{
Mixed-marker approach suggests maternal philopatry and sex-biased behaviours of narrow sawfish Anoxypristis cuspidata
}

\author{
Madeline E. Green ${ }^{1,2,3, *}$, Blanche R. D'Anastasi ${ }^{3,4}$, Jean-Paul A. Hobbs ${ }^{5}$, \\ Kevin Feldheim ${ }^{6}$, Rory McAuley ${ }^{7}$, Stirling Peverell ${ }^{8}$, Jason Stapley ${ }^{8}$, \\ Grant Johnson ${ }^{9}$, Sharon A. Appleyard ${ }^{10}$, William T. White ${ }^{10}$, \\ Colin A. Simpfendorfer ${ }^{1}$, Lynne van Herwerden ${ }^{1,3}$
}

\footnotetext{
${ }^{1}$ Centre for Sustainable Tropical Fisheries and Aquaculture \& College of Science and Engineering, James Cook University, Townsville, Queensland 4814, Australia

${ }^{2}$ Institute for Marine and Antarctic Studies, University of Tasmania, Hobart, Tasmania 7001, Australia

${ }^{3}$ College of Science and Engineering, James Cook University, Townsville, Queensland 4814, Australia ${ }^{4}$ AIMS@JCU, James Cook University, Townsville, Queensland 4811, Australia

${ }^{5}$ Department of Environment and Agriculture, Curtin University, Bentley, Western Australia 6102, Australia ${ }^{6}$ Pritzker Laboratory for Molecular Systematics and Evolution, The Field Museum, Chicago, Illinois 60605, USA

${ }^{7}$ Western Australian Government, Department of Fisheries, Western Australia 6850, Australia

${ }^{8}$ Queensland Department of Primary Industries and Fisheries, Northern Fisheries Centre, Queensland 4000, Australia

${ }^{9}$ Department of Primary Industries and Fisheries, Northern Territory Government 0828, Australia

${ }^{10}$ CSIRO National Research Collections Australia; CSIRO Oceans and Atmosphere, Hobart 7001, Australia
}

\begin{abstract}
The narrow sawfish Anoxypristis cuspidata belongs to the most endangered family of chondrichthyan fishes, the sawfishes (Pristidae). This species has undergone significant declines in geographic range and abundance due to anthropogenic activities including fishing and habitat destruction. Very little is known of adult movements within its distribution. In order to better manage and protect this endangered species, understanding patterns of habitat use, connectivity and behaviour is important. Using a combination of partial mitochondrial sequences (control region [CR] and NADH dehydrogenase 4 [ND4]) and nuclear markers (microsatellites), this study assessed the genetic population structure of $A$. cuspidata in Australia and Papua New Guinea. Significant population structuring using mitochondrial DNA was found between the east Australian coast, Gulf of Papua and Gulf of Carpentaria (using concatenated CR and ND4 markers) (analysis of molecular variance [AMOVA], $\Phi_{\mathrm{ST}}=0.082, \mathrm{p}=<0.001$ ). In contrast, no population structure was evident across northern Australia using nuclear microsatellite loci $\left(F_{\mathrm{ST}}=0.012, \mathrm{p}=\right.$ 1.000). Our results suggest that a combination of historic genetic drift, maternal natal philopatry and possible male-biased dispersal likely drive the genetic patterns observed. Given the endangered status and lack of knowledge for A. cuspidata, this study presents important insights that may be used to inform management efforts.
\end{abstract}

KEY WORDS: Pristidae $\cdot$ Genetics $\cdot$ Indo-Pacific $\cdot$ Mitochondrial DNA $\cdot$ Microsatellites

\section{INTRODUCTION}

Sawfishes are a unique group of benthic rays consisting of 5 species separated into 2 genera: Pristis and Anoxypristis (Faria et al. 2013). Characterised by

*Corresponding author: madeline.green@utas.edu.au a large toothed rostrum, sawfish are commonly distributed in shallow coastal and estuarine environments of tropical and subtropical regions (Last \& Stevens 2009). All sawfish species have undergone significant declines in geographic range and abun-

(C) The authors 2018. Open Access under Creative Commons by Attribution Licence. Use, distribution and reproduction are unrestricted. Authors and original publication must be credited. 
dance due to anthropogenic pressures including fisheries exploitation, pollution (e.g. mining activity) and habitat loss (Simpfendorfer 2000, Seitz \& Poulakis 2006, Dulvy et al. 2016). As a result, sawfish are considered the most endangered family within the class Chondrichthyes (Dulvy et al. 2014). The declining global status of sawfish populations has led to all species being listed as either Endangered or Critically Endangered under the International Union for the Conservation of Nature Red List of Threatened Species (Carlson et al. 2013, D'Anastasi et al. 2013, Kyne et al. 2013a,b, Simpfendorfer 2013), included in Appendix I of the Convention on Trade in Endangered Species (Faria et al. 2013) and included in Appendix I and II of the Convention on Migratory Species (CMS) (COP11, report Annex VII; CMS 2014).

Sawfishes are protected nationally in Australia: 3 Pristis species are listed as Vulnerable under the Environmental Protection and Biodiversity Conservation Act (C'th) (1999) and 'no take' restrictions are in place across all northern states. Australia is considered one of the last strongholds for sawfish (Morgan et al. 2011, Dulvy et al. 2016), with 4 of the 5 species found in northern waters (Last \& Stevens 2009). Recent reports from Papua New Guinea (PNG), a neighbouring nation to Australia, have indicated the presence of 4 sawfish species (Anoxypristis cuspidata, Pristis pristis, P. zjisron and P. clavata) within its waters (White et al. 2017). It is thought PNG may provide suitable habitat given the unexpected persistence of sawfish in the region. Due to a lack of historic information, the importance of PNG for sawfish has been under-assessed. Investigations into the current status of sawfish in the region are urgently required, given that no protective measures are currently in place.

The narrow sawfish $A$. cuspidata is considered the most abundant member of the sawfish family in Australian waters (Peverell 2005) despite undergoing substantial global declines of $>50 \%$ (Dulvy et al. 2014). Their relatively high abundance is often attributed to their life-history characteristics, which include higher growth rates, increased fecundity (sexual maturity at 2-3 yr, annual breeding) and shorter life expectancy $(9 \mathrm{yr})$ than other sawfish species (Dulvy et al. 2016). Narrow sawfish are commonly found inshore, at depths of 10-40 m (Peverell 2005, Last \& Stevens 2009). Ontogenetic, sex-biased and seasonal behaviours drive A. cuspidata to occupy varying ecological niches across its lifespan (Peverell 2005, Tobin et al. 2014). Adults are commonly found in offshore waters at depths of $\sim 40 \mathrm{~m}$, while juveniles and pregnant females are found in shallow inshore and estuarine habitats at depths of less than $15 \mathrm{~m}$ (Peverell 2005). Commercial net and trawl fishing often pose a risk as the frequency, locality and types of fishing gear used inadvertently catch all sawfish size classes (as by catch) (Peverell 2005, Devitt et al. 2015). Moreover, juvenile and pregnant females are disproportionately vulnerable to habitat loss as a result of coastal anthropogenic pressures, due to a strong reliance on shallow coastal environments as nurseries (Devitt et al. 2015, Adkins et al. 2016, Dulvy et al. 2016).

In recent years, our understanding of sawfish ecology in the Indo-Pacific has advanced considerably (Peverell 2005, Thorburn et al. 2007, D'Anastasi 2010, Morgan et al. 2011, Phillips et al. 2011, Tobin et al. 2014, White et al. 2017). However, there still remains limited information regarding $A$. cuspidata population structure, sex-biased dispersal behaviours and use of nursery grounds. An absence of conventional tagging studies (due to high post-release mortality associated with tagging) (Devitt et al. 2015) highlights the importance of population genetic analyses to delineate population structure (Simpfendorfer et al. 2016). Available ecological information is primarily for juvenile and sub-adult classes, as they are most commonly captured in fisheries (Peverell 2005, Tobin et al. 2014). However, information on movement and connectivity of both juvenile and adult $A$. cuspidata remains unknown. Earlier assessments of female-mediated population structure in $A$. cuspidata in northern Australia, using mitochondrial DNA (mtDNA) control region (CR) sequences, revealed significant structure between the east coast of Australia and both the Gulf of Carpentaria and northwestern Australia (analysis of molecular variance [AMOVA], $\Phi_{\mathrm{ST}}=0.016, \mathrm{p}=<0.01$ ) (D'Anastasi et al. 2010, B.R.D. unpubl. data), consistent with findings for other sawfish species using the same marker (Phillips et al. 2011). To date, no ecological or genetic studies have included $A$. cuspidata populations inhabiting nearby PNG waters.

Establishing effective management approaches for sharks and rays can be facilitated through improved understanding of aspects of their biology, including behaviours specific to age and sex (Harry et al. 2011). Additionally, the identification of discrete areas in which specific life stages may occur (e.g. nursery areas) can also help prioritise management efforts (Heupel et al. 2007). For A. cuspidata, it is yet to be confirmed if dispersal behaviours exhibited by males and females differ. These behaviours can be evaluated using genetic markers with different modes of inheritance (mitochondrial 
versus nuclear DNA) when assessing population structure (Chapman et al. 2015). Furthermore, mitigating the effects of overexploitation posed by anthropogenic activities is paramount to ensuring the survival of sawfish. Recently, there have been a number of sawfish recovery and conservation plans announced with both global and Australia-wide focus (Harrison \& Dulvy 2014, Australian Department of the Environment 2015). Because of the endangered status of $A$. cuspidata, limited knowledge and call for strategic conservation efforts, this study characterised the genetic connectivity and stock structure of A. cuspidata in northern Australia and the Gulf of Papua, PNG.

\section{MATERIALS AND METHODS}

\section{Sampling}

Fin clips from Anoxypristis cuspidata were sourced from scientific sampling efforts and commercial fisheries between 2000 and 2015 from northern Australia and PNG (Fig. 1). Due to the opportunistic nature of collection and the rarity of this species, sample sizes and measurements collected varied between locations. For some samples, size and sex measurements were not recorded and are therefore unavailable.

\section{Laboratory procedures}

Genomic DNA (gDNA) was extracted from fin clips using either a modified salting-out method (Sunnucks \& Hales 1996) or a Wizard ${ }^{\circledR}$ SV Genomic DNA purification system (Promega). A portion of the mtDNA CR was amplified following D'Anastasi (2010), while NADH dehydrogenase 4 (ND4) was amplified using primers ND4-F 5'-TGA CTA CCA AAA GCT CAT GTA GAA GC-3' and Leu-Scyliorhinus 5'-CAT AAC TCT TGC TTG GAG TTG CAC CA-3' (Naylor et al. 2005). PCR was performed using $5 \mu \mathrm{l} 10 \mathrm{X}$ Buffer (Promega), $0.125 \mu \mathrm{l}$ Taq polymerase (Promega), $1.0 \mathrm{mM} \mathrm{MgCl}_{2}, 5 \mu \mathrm{M}$ of each primer, $0.5 \mu \mathrm{M}$ dNTP and $1 \mu \mathrm{l}$ (10-30 ng $\left.\mathrm{\mu l}^{-1}\right)$ DNA in $25 \mu \mathrm{l}$ volumes. PCR conditions for both fragments included an initial denaturation step at $94^{\circ} \mathrm{C}$ for $60 \mathrm{~s}$, followed by a touchdown protocol with denaturation at $94^{\circ} \mathrm{C}$ for $60 \mathrm{~s}$, annealing at $54^{\circ} \mathrm{C}$ for $30 \mathrm{~s}$ and extension at $72^{\circ} \mathrm{C}$ for $90 \mathrm{~s}$ across 5 cycles; the next 5 cycles were performed as stated above with an annealing temperature of $52^{\circ} \mathrm{C}$ and the final 25 cycles were as above, with an annealing temperature of $50^{\circ} \mathrm{C}$. After a total of 35 cycles, a final extension step was performed at $72^{\circ} \mathrm{C}$ for $5 \mathrm{~min}$. PCR reactions were undertaken in either a Bio-Rad C1000 Thermal Cycler (Bio-Rad) or an Applied Biosystem GeneAmp ${ }^{\circledR}$ PCR system 9700 (Life Technologies, Thermo Fisher Scientific).

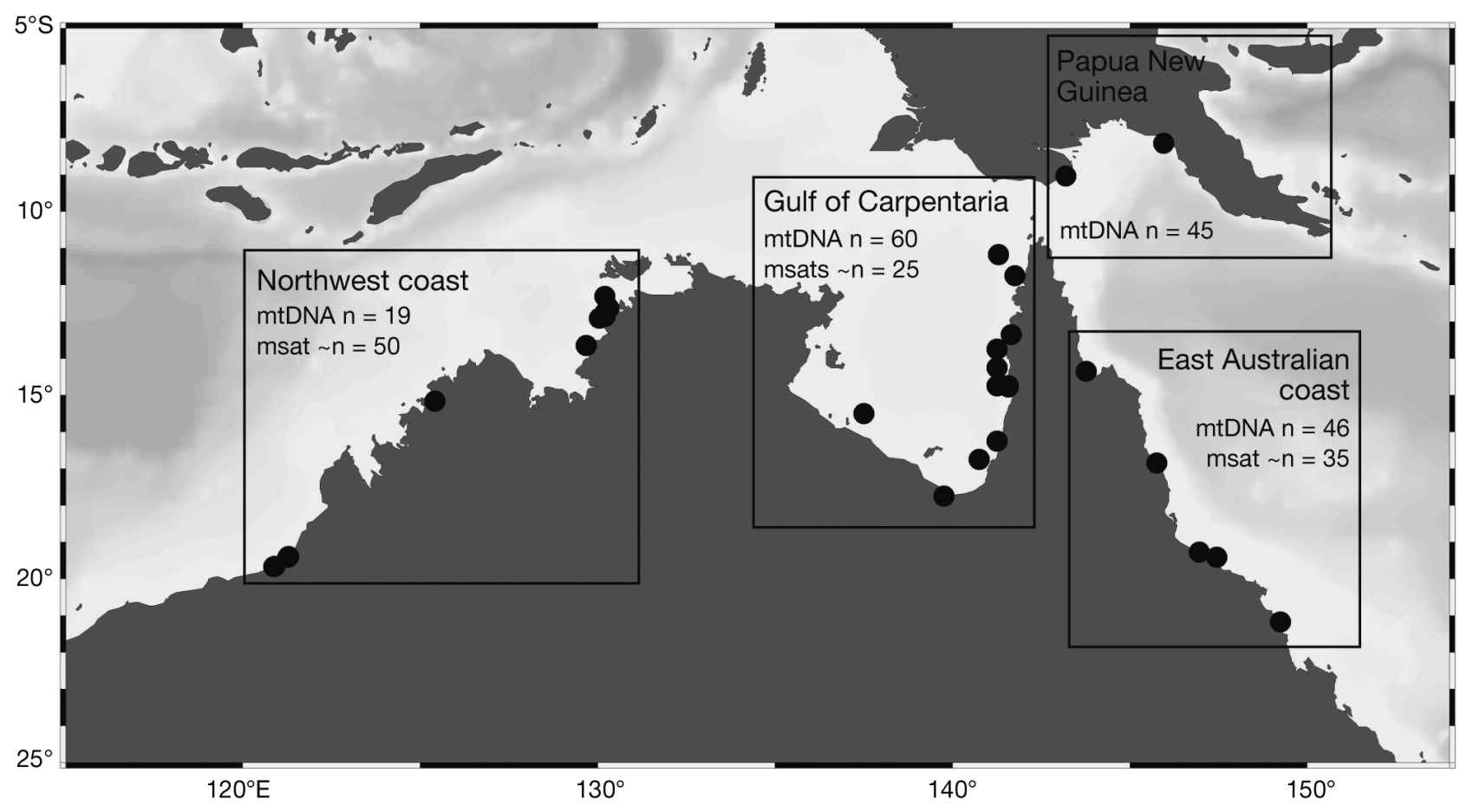

Fig. 1. Approximate sampling locations and sample sizes per genetic marker for Anoxypristis cuspidata in Australia and Papua New Guinea. mtDNA: mitochondrial DNA; msat: microsatellite 
Table 1. Motif, sequence, fluorescent dye, annealing temperature $\left(T_{\mathrm{a}}\right)$, size range and multiplex for the Anoxypristis cuspidata microsatellite loci screened in population samples

\begin{tabular}{|c|c|c|c|c|c|}
\hline Locus & $\begin{array}{c}\text { Repeat } \\
\text { motif }\end{array}$ & Primer sequence 5'-3' & $T_{\mathrm{a}}\left({ }^{\circ} \mathrm{C}\right)$ & $\begin{array}{l}\text { Size range } \\
\text { (bp) }\end{array}$ & $\begin{array}{c}\text { Multi- } \\
\text { plex }\end{array}$ \\
\hline \multirow[t]{2}{*}{ Ancu86 } & $(\mathrm{TG})_{12}$ & [FAM] F-CCC GAT GAA CAC AAC TTT CA & & & \\
\hline & & R-TTG AAT GAA TGA CCC CAA ACT & $57-55-53$ & $142-172$ & A \\
\hline \multirow[t]{2}{*}{ Ancu76 } & $(\mathrm{TAGA})_{12}$ & [NED] F-CAG TGC AAG ACA TAA AAA TTA CT & & & \\
\hline & & R- CCT CAG TTG TCC TCC CAT TG & $57-55-53$ & $152-182$ & A \\
\hline \multirow[t]{2}{*}{ Ancu143 } & $(\mathrm{TATC})_{26}$ & [VIC] F- ATC CAC CCA TGA ATT TAG TTA TTT & & & \\
\hline & & R- CCA TGC AAA CAA ATC AAA GG & $57-55-53$ & $242-272$ & A \\
\hline \multirow[t]{2}{*}{ Ancu162 } & $(\mathrm{AC})_{42}$ & [VIC] F-CCT CCT TAT CCC TTC TGT CG & & & \\
\hline & & R- GAC CCG AAG CAC TGA TGT TT & $57-55-53$ & $167-197$ & B \\
\hline \multirow[t]{2}{*}{ Ancu116 } & $(\text { TATC })_{11}$ & [FAM] F- ACC GCT ATT TCC GAA TGA TG & & & \\
\hline & & R- GGT CAT TAC CCA GGG ACA GC & $57-55-53$ & $207-237$ & B \\
\hline \multirow[t]{2}{*}{ Ancu $123^{\mathrm{a}}$} & $(\mathrm{TG})_{36}$ & [PET] F-GTC AGC ACC GGG TCA CTA TT & & & \\
\hline & & R- TCA TGA CCA ATG CTG ACT TGA & $57-55-53$ & $202-232$ & $\mathrm{~B}$ \\
\hline \multirow[t]{2}{*}{ Ancu152a } & $\left(\mathrm{TATC}_{15}\right.$ & [NED] F-GCT GCC CCA GAA CAC TCT AC & & & \\
\hline & & AGG GAG ATT TGA ATG TTG CAG & NA & $240-300$ & B \\
\hline
\end{tabular}

PCR products were sequenced bi-directionally using BigDye ${ }^{\circledR}$ Terminator v3.1 cycle sequencing chemistry (Life Technologies) as per the manufacturer's recommendations. Cycle sequenced products were purified using the CleanSEQ kit (Beckman Coulter) and run on an ABI 3130XL AutoDNA sequencer (Life Technologies). Sequences were edited, aligned (using MUSCLE; Edgar 2004) and trimmed, with the CR and ND4 sequences concatenated using Geneious vR6.1 (Kearse et al. 2012). Aligned and edited partial mtDNA CR sequences for samples collected in northern Australia from the northwest coast, Gulf of Carpentaria and east coast were provided by B.R.D. ( $\mathrm{n}=164)$ (GenBank references JQ026198.1，JQ026199.1，JQ026200.1，JQ026201.1， JQ026202.1 and JQ026203.1) (D'Anastasi 2010).

Microsatellite markers were developed following the enrichment protocol of Glenn \& Schable (2005). Genomic DNA from one individual was digested with RsaI and XmnI, and SuperSNX24 linkers were igated onto the ends of the resulting fragments. Five biotinylated tetranucleotide probes, $(\mathrm{ACAT})_{6},(\mathrm{AGAT})_{8}$, $(\mathrm{AACT})_{8},(\mathrm{AAAT})_{8},(\mathrm{AAGT})_{8}$, were hybridized to these fragments and added to streptavidin-coated magnetic beads (Dynabeads ${ }^{\circledR}$ ).

We developed primers flanking core microsatellite repeats in the sequenced enriched sawfish DNA fragments using Primer3 (http://frodo.wi.mit.edu/ cgi-bin/primer3/primer3_www.cgi). Characterisation identified 7 putative microsatellite markers. Of these, forward primers were fluorescently labelled (FAM, NED, PET or VIC) and grouped into 2 multiplex reactions, with 4 and 3 markers per multiplex, respec- tively (Table 1). Optimization included PCR in $10 \mu \mathrm{l}$ volumes containing $5 \mu \mathrm{l}$ 2X TYPE-IT master mix (Qiagen), $1 \mu$ multiplexed primers at final concentrations of $10 \mu \mathrm{M}$, and $1 \mu \mathrm{l}$ DNA (15-40 ng). PCR thermal conditions included an initial denaturation step at $95^{\circ} \mathrm{C}$ for $5 \mathrm{~min}$, a touchdown protocol with 5 cycles of $95^{\circ} \mathrm{C}$ for $30 \mathrm{~s}, 57^{\circ} \mathrm{C}$ for $90 \mathrm{~s}$ and $72^{\circ} \mathrm{C}$ for $30 \mathrm{~s}$, followed by 5 cycles at $55^{\circ} \mathrm{C}$ for annealing and a final 22 cycles at $53^{\circ} \mathrm{C}$ for annealing. A final extension was performed at $60^{\circ} \mathrm{C}$ for $30 \mathrm{~min}$. All PCR reactions were completed using a Bio-Rad C1000 Thermal Cycler.

\section{Data analysis}

For mtDNA sequence analyses, the number of haplotypes $(H)$, haplotype diversities $(h)$ and nucleotide diversities $(\pi)$ were calculated in Arlequin v3.5 (Excoffier \& Lischer 2010). A minimum spanning tree (MST) was constructed using output data from Arlequin v3.5 to visualise the spatial distribution of haplotypic diversity. Tests for past population expansions using Fu's $F_{\mathrm{s}}$ were conducted in DnaSP v6 (Rozas et al. 2017). Global tests for differentiation, AMOVA calculations and pairwise $\Phi_{\mathrm{ST}}$ including accompanying $\mathrm{p}$-values for regional locations were computed using the distance matrix model in Arlequin v3.5 (Excoffier \& Lischer 2010).

Genetic diversity metrics for the microsatellite markers included mean number of alleles $\left(N_{\mathrm{a}}\right)$, allelic richness $\left(A_{R}\right)$, observed and expected heterozygosities $\left(H_{0}, H_{\mathrm{e}}\right)$ and inbreeding coefficients $\left(F_{\mathrm{IS}}\right)$, which were calculated in the $\mathrm{R}$ package diveRsity (Keenan 
et al. 2013). Hardy-Weinberg equilibrium calculations and linkage disequilibrium (LD) was calculated in Genepop 4.0 (Rousset 2008) using the Markov chain algorithm, with a dememorization of 100000 over 20 batches and 10000 iterations per batch in order to detect (and exclude) loci not conforming to the underlying population genetic assumptions. The presence of null alleles and effects of allele dropout were evaluated in FreeNA (Chapuis \& Estoup 2007). For estimates of population differentiation, samples missing alleles at 3 or more loci were excluded so that each individual had at least 3 loci and each locus had $<5 \%$ missing data. AMOVA and estimates of global differentiation using $F_{\mathrm{ST}}$ and accompanying $\mathrm{p}$-values were calculated using the haplotype frequency model in Arlequin v3.5. For all pairwise analyses, the initial significance levels $(\mathrm{p}<0.05)$ were adjusted for simultaneous pairwise comparisons using the false discovery rate described in Narum (2006) to reduce the likelihood of Type I errors.

\section{RESULTS}

A final mtDNA sequence alignment containing $757 \mathrm{bp}$ (269 bp and $488 \mathrm{bp}$ fragments of CR and ND4, respectively) with a GC content of 0.425 was analysed. Some samples from the northwest coast of Australia failed to amplify using CR and ND4 mtDNA primers (likely due to degradation of samples/DNA); therefore, sample size was reduced for mitochondrial results representing that region. The Gulf of Papua, east coast Australia and Gulf of Carpentaria populations all had greater than 40 individuals, while the northwest coast was represented by 19 individuals (Fig. 1, Table 2). There were 11 polymorphic sites contained in 13 individual haplotypes -4 of which were singletons (Fig. 2). Haplotype diversity ranged from 0.535 on the east coast to 0.789 on the northwest coast, with an average haplotype diversity of 0.658 across all sampled locations (Table 2).

Microsatellite results from the Gulf of Papua were unavailable, as loci did not amplify reliably. It is unknown if unreliable amplification in this population was an artefact of degraded primers. Therefore, microsatellite results presented here are for the 3 Australian locations exclusively. Six of the 7 microsatellite markers amplified reliably (Ancu152 did not amplify) and were used to genotype 123 A. cuspidata individuals from 3 regions in Australia. Of these 6 loci, 5 were suitable for population genetic analysis after an excess of null alleles was found for one locus (Ancu123) (Table 1). The average number of alleles per location (across the suitable 5 loci) was 11.2, 10.6 and 11.6 for the northwest coast, Gulf of Carpentaria and east coast, respectively; average allelic richness

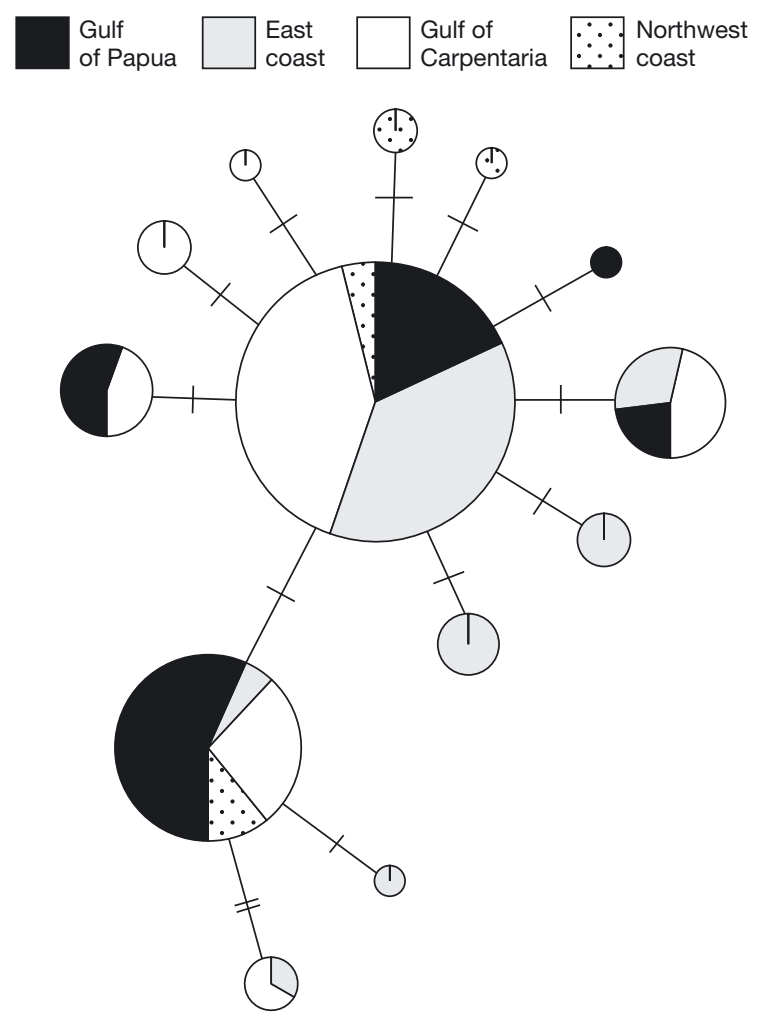

Fig. 2. Minimum spanning tree representing Anoxypristis cuspidata haplotype distributions across sampled Australian and Papua New Guinean regions. Size of circle represents frequency of individuals belonging to haplotype. Dashes represent the number of mutational changes between each haplotype, i.e. one dash is equal to a single base-pair change between haplotypes 
ranged from 9.97 to 10.60 on the northwest coast and the Gulf of Carpentaria, respectively (Table 3).

\section{Population structure and demographic history}

Global tests for differentiation and AMOVA analyses, based on mtDNA haplotype frequencies, revealed significant population structuring $\left(\Phi_{\mathrm{ST}}=\right.$ 0.082, $\mathrm{p}=<0.001$ ). Pairwise population comparisons revealed structuring between all population pairs, except the Gulf of Carpentaria and the northwest coast (Table 4). Past population expansion tests were significant for the east and northwest Australian coast populations ( $\mathrm{p}<0.03$ ). Negative Fu's $F_{\mathrm{s}}$ values were obtained for all populations (Table 2) indicating a greater than expected number of rare haplotypes within each population.

The east coast, Gulf of Carpentaria and northwest coast locations had average sample sizes of 35 , 25.4 and 50.4, respectively, across the 5 microsatellite loci (Table 3). No significant population structure was identified using microsatellite loci in AMOVA analyses $\left(F_{\mathrm{ST}}=0.012, \mathrm{p}=1.000\right)$, and genetic diversity $\left(H_{0}\right)$ was $>80 \%$. Additionally, genetic variation within putative populations (>98\% of variation) exceeded inter-population variation. This suggests homogeneity across samples; thus, no further pairwise comparisons were considered.

\section{DISCUSSION}

This study marks the first assessment of female- and malemediated genetic structure of Anoxypristis cuspidata, using a mixed-marker approach (mtDNA and nuclear markers). Our findings of significant mtDNA structuring between all population pairs, excluding the Gulf of Carpentaria and northwest coast, is likely driven by the effects of genetic drift in combination with female-mediated philopatry. In contrast, microsatellite results identified no significant population structuring, which may represent connectivity facilitated by male-biased dispersal across the Australian-Papuan region.

\section{Mitochondrial DNA}

Elasmobranch mtDNA evolutionary rates are low (Martin et al. 1992), and sawfish mitochondrial diversity is at the lower end of the range for elasmo-

Table 3. Anoxypristis cuspidata microsatellite results per region (total and average). n: number of samples; $N_{\mathrm{A}}$ : number of alleles, $A_{\mathrm{R}}$ : allelic richness, $H_{\mathrm{o}}$ : observed heterozygosity $\pm \mathrm{SE}_{i} H_{\mathrm{e}}$ : expected heterozygosity $\pm \mathrm{SE}_{i} \mathrm{p}_{\mathrm{HWE}}$ : HardyWeinberg equilibrium $p$-value (bold indicates significance); $F_{\mathrm{IS}}$ : inbreeding coefficient. Asterisks indicate null allele frequencies $>0.009$

\begin{tabular}{|c|c|c|c|c|c|c|}
\hline Locus & Ancu116 & Ancu162 & Ancu 76 & Ancu143 & Ancu86 & Average \\
\hline \multicolumn{7}{|c|}{ East coast Australia } \\
\hline $\mathrm{n}$ & 35 & 35 & 35 & 35 & 35 & 35 \\
\hline$N_{\mathrm{A}}$ & 8 & $16^{*}$ & $13^{*}$ & 14 & 7 & 11.6 \\
\hline$A_{\mathrm{R}}$ & 7.22 & 14.39 & 6.42 & 12.13 & 12.10 & 10.42 \\
\hline$H_{\mathrm{o}}$ & 0.800 & 0.771 & 0.628 & 0.971 & 0.885 & 0.811 \\
\hline$H_{\mathrm{e}}$ & 0.694 & 0.853 & 0.734 & 0.861 & 0.884 & 0.806 \\
\hline $\mathrm{p}_{\text {HWE }}$ & 0.983 & 0.007 & $<0.001$ & 0.202 & 0.758 & \\
\hline$F_{\mathrm{IS}}$ & -0.152 & 0.095 & 0.144 & -0.127 & -0.001 & -0.008 \\
\hline \multicolumn{7}{|c|}{ Gulf of Carpentaria } \\
\hline $\mathrm{n}$ & 26 & 26 & 26 & 24 & 25 & 25.4 \\
\hline$N_{\mathrm{A}}$ & 9 & $16^{*}$ & $12^{*}$ & 11 & 5 & 10.6 \\
\hline$A_{\mathrm{R}}$ & 9.00 & 16.00 & 5.00 & 11.00 & 12.00 & 10.60 \\
\hline$H_{\mathrm{o}}$ & 0.807 & 0.769 & 0.576 & 1.000 & 0.960 & $0.823 \pm 0.016$ \\
\hline$H_{\mathrm{e}}$ & 0.746 & 0.904 & 0.657 & 0.875 & 0.859 & $0.809 \pm 0.046$ \\
\hline $\mathrm{p}_{\mathrm{HWE}}$ & 0.209 & 0.262 & 0.065 & 0.147 & 0.076 & \\
\hline$F_{\mathrm{IS}}$ & -0.08 & 0.149 & 0.122 & -0.141 & -0.117 & -0.014 \\
\hline \multicolumn{7}{|c|}{ Northwest coast Australia } \\
\hline $\mathrm{n}$ & 53 & 43 & 53 & 50 & 53 & 50.4 \\
\hline$N_{\mathrm{A}}$ & 8 & $20^{*}$ & 12 & 12 & 4 & 11.2 \\
\hline$A_{\mathrm{R}}$ & 6.19 & 17.13 & 3.99 & 11.32 & 11.20 & 9.97 \\
\hline$H_{\mathrm{o}}$ & 0.867 & 0.674 & 0.679 & 0.920 & 0.886 & $0.806 \pm 0.119$ \\
\hline$H_{\mathrm{e}}$ & 0.706 & 0.894 & 0.622 & 0.877 & 0.893 & $0.799 \pm 0.056$ \\
\hline $\mathrm{p}_{\mathrm{HWE}}$ & 0.313 & $<0.001$ & 0.671 & 0.711 & 0.724 & \\
\hline$F_{\mathrm{IS}}$ & -0.227 & 0.246 & -0.091 & -0.048 & 0.007 & -0.023 \\
\hline
\end{tabular}

Table 4. Anoxypristis cuspidata mtDNA pairwise $\Phi_{\mathrm{ST}}$ values obtained using Arlequin v3.5. Above diagonal: p-values; below diagonal: $F_{\mathrm{ST}}$ values. Asterisks indicate significant $\mathrm{p}$-value with false discovery rate correction as per Narum (2006)

\begin{tabular}{|lcccc|}
\hline Location & $\begin{array}{c}\text { Gulf } \\
\text { of Papua }\end{array}$ & $\begin{array}{c}\text { East coast } \\
\text { Australia }\end{array}$ & $\begin{array}{c}\text { Gulf of } \\
\text { Carpentaria }\end{array}$ & $\begin{array}{c}\text { Northwest coast } \\
\text { Australia }\end{array}$ \\
\hline Gulf of Papua & - & $<0.001^{*}$ & $0.016^{*}$ & $0.029^{*}$ \\
East coast Australia & 0.200 & - & $0.004^{*}$ & $<0.001^{*}$ \\
Gulf of Carpentaria & 0.046 & 0.054 & - & 0.177 \\
Northwest coast Australia & 0.054 & 0.133 & 0.017 & - \\
\hline
\end{tabular}


branchs (see D'Anastasi, 2010, Phillips et al. 2017). Using multiple markers to increase the amount of variability available in this scenario typically enhances power to detect structure (Ryman \& Palm 2006). Our approach of analysing concatenated CR and ND4 sequences increased the number of parsimony-informative nucleotide sites available and confirmed findings of genetic structuring between regions based on CR alone (D'Anastasi 2010, B.R.D. unpubl. data), providing greater confidence in our results.

Haplotypes across the Australian-Papuan region sampled show a shallow evolutionary history for $A$. cuspidata, with low nucleotide diversity and few mutations between haplotypes. In terms of population differentiation, all populations have relatively little divergence and all share the 2 most common haplotypes. The northwest coast and the Gulf of Carpentaria appear to be a single population, while the east coast and the Gulf of Papua show significant differentiation from all populations.

The lack of genetic structuring between the northwest coast and the Gulf of Carpentaria may have multiple explanations, given that structure is detected at smaller spatial scales (PNG and east coast). Gene flow may be ongoing, but this is unlikely given the presence of numerous private haplotypes in each location. Alternatively, genetic structure may be masked due to a number of factors, including: the large geographic scales of regional grouping in the northwest coast sample (which spans biogeographic and genetic breaks - see DiBattista et al. 2017), infrequent migrations between regions over evolutionary time scales, and insufficient time for genetic differentiation between samples with a shared evolutionary history, e.g. following a range expansion from northwest Australia into the previously landlocked Gulf of Carpentaria (see de Bruyn et al. 2004). Additional data collected from finer spatial scales and additional mtDNA markers are required to further assess this.

Our results indicate the presence of matrilineal structure, particularly between the east Australian coast and the Gulf of Papua. The observed structure, characterised by a few common haplotypes shared across regions, numerous private haplotypes and a shallow evolutionary history is likely the combined effect of genetic drift and a bottleneck/founder effect. The effect of genetic drift, where haplotype frequencies change with the random loss or retention of haplotypes through time, is enhanced in small or declining populations such as sawfish (Dulvy et al. 2014). Rare haplotypes are more likely to be lost through time, which can cause genetic diversity reductions (assuming selection, migration or mutations are not occurring) (Lacy 1987, Slatkin, 1987). Another possible factor defining matrilineal population structure in A. cuspidata populations is the presence of founder/bottleneck events that precede range expansions (e.g. into the Gulf of Carpentaria), which would account for observed high haplotype and low nucleotide diversities (e.g. as per Fauvelot et al. 2003). Similar genetic drift and bottlenecks were reported for Pristis sawfish populations from northern Australia and considered to reflect founder events that occurred during range expansions into new habitats during their evolutionary history in northern Australia (Phillips et al. 2017). Genetic drift/bottleneck events as a driver of population structure is supported by the finding of negative Fu's $F_{\mathrm{s}}$ values, which indicate the presence of an excess of private mutations that would not be expected if populations had reached equilibrium (Fu 1997).

The behaviour of adult A. cuspidata may also enhance the effects of genetic drift for populations across the region. It is well documented that many female sharks and rays return to the same region to give birth, a phenomenon referred to as parturition site fidelity or maternal natal philopatry (see Chapman et al. 2015 for definitions). This behaviour is likely the result of selection favouring females that return to give birth in areas where previous generations have been most successful (Hueter et al. 2004, Portnoy et al. 2015). Maternal natal philopatry has been identified in numerous other elasmobranchs displaying sex-biased dispersal (Pardini et al. 2001, Keeney et al. 2005, Portnoy et al. 2010, Daly-Engel et al. 2012, Portnoy et al. 2015, Phillips et al. 2016), including $P$. pristis (based on comparable sample sizes and number of loci [6] to A. cuspidata) (Phillips et al. 2011, 2016). The significant mtDNA values reported here in combination with characteristics such as demographic aggregation (by sex and age) (Peverell 2005, Tobin et al. 2014, Adkins et al. 2016) demonstrate that $A$. cuspidata have characteristics associated with maternal natal philopatry. However, additional sampling is required (including metadata of size and sex of individuals sampled) to enable separate female and juvenile testing for more accurate estimates of philopatry.

\section{Microsatellites}

In contrast to evidence of maternal natal philopatry derived from mtDNA data, microsatellite data failed 
to detect population structure for A. cuspidata. Together, these findings suggest male-biased dispersal in the presence of female natal philopatry. Whilst we interpret these results with some caution, given the large geographic scales encompassed in regional groups and the limited number of loci used, these findings are consistent with those for P. pristis, a sawfish that is highly reliant on freshwater reaches of estuaries for juvenile survival (Phillips et al. 2016). In contrast, sex-biased dispersal was not evident for 2 other sawfishes, P. zijsron and P. clavata, which, like A. cuspidata, are not reliant on freshwater for juvenile survival, but which had matching population structuring for both sexes based on both mtDNA and microsatellites (Phillips et al. 2011, 2016).

Male-biased dispersal may provide a number of benefits for populations by reducing inbreeding (Pusey 1987), dispersing local resource competition (Greenwood 1980) and reducing mate competition (Dobson 1982). Phillips et al. $(2016,2017)$ hypothesised that differing patterns in habitat use may explain the observed differences in dispersal bias among Pristis sawfish. However, our findings suggest involvement of other drivers. In particular, different morphological characteristics between sawfish species displaying sex-biased dispersal and those without are noteworthy. A. cuspidata and P. pristis both possess a large ventral lobe on the caudal fin (Faria et al. 2013). In general, fins with a high aspect ratio and distinct ventral lobe, similar to A. cuspidata fins, and to a lesser extent $P$. pristis fins, are considered indicators of pelagic swimmers that spend limited time on the benthos (Thomson \& Simanek 1977). Migration of distances greater than $1000 \mathrm{~km}$ is possible given the $A$. cuspidata caudal fin shape and availability of suitable habitat across northern Australia (Devitt et al. 2015).

\section{CONCLUSIONS}

This study has provided important population genetic information using mtDNA and microsatellite markers for Anoxypristis cuspidata; particularly, evidence of possible maternal natal philopatry and sexbiased male dispersal. Regional mtDNA genetic diversity may be prone to erosion through genetic drift (Phillips et al. 2011). However, more maternal and biparental genetic data are required to confirm structure at smaller geographic scales, in order to validate whether A. cuspidata exhibits maternal natal philopatry coupled with paternal dispersal. Based on current evidence, a decline in female numbers in a particular region is unlikely to be replen- ished by regional migration, suggesting that a regional management approach is required for maternal stocks and their pups. Inter-regional connectivity, identified by microsatellites, has provided the first evidence for male-biased dispersal in A. cuspidata over spatial scales exceeding $1000 \mathrm{~km}$. This requires confirmation with additional data (e.g. more microsatellites or single nucleotide polymorphisms, sampling over finer spatial scales) before management implications can be confidently resolved. If confirmed, cross-jurisdictional management may be required for male stocks. Lastly, assessing genetic connectivity represented in the nuclear genome between Australia and neighbouring countries, such as PNG and Indonesia, should be expanded to better understand A. cuspidata source-sink dynamics and how different conservation approaches between countries are affecting the conservation outcomes for this species.

Acknowledgements. This project was funded by James Cook University, the Australian Geographic Bayer Boost Society, the Australian Centre for International Agricultural Research (ACIAR; project FIS/2012/102), PNG National Fisheries Authority (PNG-NFA), the Commonwealth Scientific and Industrial Research Organisation (CSIRO), the Seaworld Research and Rescue Foundation and the Holsworth Wildlife Research Endowment. Special thanks to Darbi Jones, Elien Boogaerts, Julie Traweek and Joern Villwock for undertaking many DNA extractions. We thank David Morgan, Nicole Phillips and Jimmy White for Australian samples. The PNG samples were obtained as part of a project funded by the ACIAR, with thanks to Drs. Chris Barlow and Jes Sammut for their support; Brian Kumasi, Luanah Yaman, Leban Gisawa, Leontine Baje, Benthly Sabub, Rickson Lis, Thomas Usu and Ludwig Kumoru from PNG-NFA for their support and collaboration on this project; the fishers of the longline vessels and a special thanks to the PNG-NFA on-board fisheries observers who collected the data and tissue samples during prawn trawl surveys: Baera Nawia, Ian Tony, Ronald Wala and Siwen Ohuesaho; Jonathan Smart (JCU) for assistance in the field; and the villagers and fish buyers (Philamarine) in the Daru and Katatai region of the Western Province who allowed us to take samples from dried specimens.

\section{LITERATURE CITED}

Adkins ME, Simpfendorfer CA, Tobin AJ (2016) Large tropical fishes and their use of the nearshore littoral, intertidal and subtidal habitat mosaic. Mar Freshw Res 67: 1534-1545

Australian Department of the Environment (2015) Sawfish and River Sharks Multispecies Recovery Plan. www. environment.gov.au/resource/recovery-plan-sawfishand-river-sharks

Carlson JK, Wiley TR, Smith K (2013) Pristis pectinata. The IUCN Red List of Threatened Species. http://dx.doi. org/10.2305/IUCN.UK.2013-1.RLTS.T18175A43398238.en 
Chapman DD, Feldheim KA, Papastamatiou YP, Hueter RE (2015) There and back again: a review of residency and return migrations in sharks, with implications for population structure and management. Annu Rev Mar Sci 7: 547-570

Chapuis MP, Estoup A (2007) Microsatellite null alleles and estimation of population differentiation. Mol Biol Evol 24: 621-631

CMS (COP11 of the Convention on Migratory Species) (2014) Conservation of migratory sharks and rays. In: Report on the Eleventh Meeting of the Conference of Parities (COP 11) to the Convention on the Conservation of Migratory Species (CMS) on Wild Animals, Quito, Ecuador, 4-9 November 2014. www.cms.int/sites/default/ files/document/Appendices_COP11_E_version5June2015. pdf

D'Anastasi BR (2010) Conservation genetics of the critically endangered narrow sawfish, Anoxypristis cuspidata in northern Australia. Honours thesis, James Cook University, Townsville

D'Anastasi BR, Simpfendorfer CA, van Herwerden L (2013) Anoxypristis cuspidata. The IUCN Red List of Threatened Species. http://dx.doi.org/10.2305/IUCN.UK.20131.RLTS.T39389A18620409.en

Daly-Engel TS, Seraphin KD, Holland KN, Coffey JP, Nance HA, Toonen RJ, Bowen BW (2012) Global phylogeography with mixed-marker analysis reveals male-mediated dispersal in the endangered scalloped hammerhead shark (Sphyrna lewini). PLOS ONE 7:e29986

de Bruyn M, Wilson JC, Mather PB (2004) Reconciling geography and genealogy: phylogeography of giant freshwater prawns from the Lake Carpentaria region. Mol Ecol 13:3515-3526

Devitt KR, Adams VM, Kyne PM (2015) Australia's protected area network fails to adequately protect the world's most threatened marine fishes. Glob Ecol Conserv 3:401-411

DiBattista JD, Travers MJ, Moore GI, Evans RD and others (2017) Seascape genomics reveals fine-scale patterns of dispersal for a reef fish along the ecologically divergent coast of Northwestern Australia. Mol Ecol 26:6206-6223

Dobson FS (1982) Competition for mates and predominant juvenile male dispersal in mammals. Anim Behav 30: 1183-1192

Dulvy NK, Fowler SL, Musick JA, Cavanagh RD and others (2014) Extinction risk and conservation of the world's sharks and rays. eLife 3:e00590

* Dulvy NK, Davidson LNK, Kyne PM, Simpfendorfer CA, Harrison LR, Carlson JK, Fordham SV (2016) Ghosts of the coast: global extinction risk and conservation of sawfishes. Aquat Conserv 26:134-153

Edgar RC (2004) MUSCLE: multiple sequence alignment with high accuracy and high throughput. Nucleic Acids Res 32:1792-1797

Excoffier L, Lischer HEL (2010) Arlequin suite ver 3.5: a new series of programs to perform population genetics analyses under Linux and Windows. Mol Ecol Resour 10: 564-567

Faria V, McDavitt MT, Charvet P, Wiley TR, Simpfendorfer CA, Naylor GJP (2013) Species delineation and global population structure of Critically Endangered sawfishes (Pristidae). Zool J Linn Soc 167:136-164

Fauvelot C, Bernardi G, Planes S (2003) Reductions in the mitochondrial DNA diversity of coral reef fish provide evidence of population bottlenecks resulting from Holocene sea-level change. Evolution 57:1571-1583
Fu YX (1997) Statistical tests of neutrality of mutations against population growth, hitchhiking and background selection. Genetics 147:915-925

* Glenn TC, Schable NA (2005) Isolating microsatellite DNA loci. Methods Enzymol 395:202-222

Greenwood PJ (1980) Mating systems, philopatry and dispersal in birds and mammals. Anim Behav 28:1140-1162

Harrison LR, Dulvy NK (2014) Sawfish: a global strategy for conservation. International Union for the Conservation of Nature, Species Survival Commissions, Shark Specialist Group, Vancouver

*Harry AV, Tobin AJ, Simpfendorfer CA, Welch DJ and others (2011) Evaluating catch and mitigating risk in a multispecies, tropical, inshore shark fishery within the Great Barrier Reef World Heritage Area. Mar Freshw Res 62:710-721

*Heupel MR, Carlson JK, Simpfendorfer CA (2007) Shark nursery areas: concepts, definition, characterization and assumptions. Mar Ecol Prog Ser 337:287-297

Hueter RE, Heupel MR, Heist EJ, Keeney DB (2004) Evidence of philopatry in sharks and implications for the management of shark fisheries. J Northwest Atl Fish Sci 35:239-247

Kearse M, Moir R, Wilson A, Stones-Havas S and others (2012) Geneious Basic: an integrated and extendable desktop software platform for the organization and analysis of sequence data. Bioinformatics 28:1647-1649

* Keenan K, McGinnity P, Cross TF, Crozier WW, Prodöhl PA (2013) diveRsity: an R package for the estimation and exploration of population genetics parameters and their associated errors. Methods Ecol Evol 4:782-788

Keeney DB, Heupel MR, Hueter RE, Heist EJ (2005) Microsatellite and mitochondrial DNA analyses of the genetic structure of blacktip shark (Carcharhinus limbatus) nurseries in the northwestern Atlantic, Gulf of Mexico, and Caribbean Sea. Mol Ecol 14:1911-1923

Kyne PM, Carlson JK, Smith K (2013a) Pristis pristis. The IUCN Red List of Threatened Species. http://dx.doi.org/ 10.2305/IUCN.UK.2013-1.RLTS.T18584848A18620395.en

*Kyne PM, Rigby C, Simpfendorfer CA (2013b) Pristis clavata. The IUCN Red List of Threatened Species. http:// dx.doi.org/10.2305/IUCN.UK.2013-1.RLTS.T39390A18 620389.en

Lacy RC (1987) Loss of genetic diversity from managed populations: interacting effects of drift, mutation, immigration, selection, and population subdivision. Soc Conserv Biol 1:143-158

Last PR, Stevens JD (2009) Sharks and rays of Australia, 2nd edn. CSIRO Publishing, Melbourne

*Martin AP, Naylor GJ, Palumbi SR (1992) Rates of mitochondrial DNA evolution in sharks are slow compared with mammals. Nature 357:153-155

Morgan DL, Whitty JM, Phillips NM, Thorburn DC, Chaplin JA, McAuley R (2011) North-western Australia as a hotspot for endangered elasmobranchs with particular reference to sawfishes and the northern river shark. J R Soc West Aust 94:345-358

Narum SR (2006) Beyond Bonferroni: less conservative analyses for conservation genetics. Conserv Genet 7: 783-787

Naylor GJP, Ryburn JA, Fedrigo O, Lopez A (2005) Phylogenetic relationships among the major lineages of modern elasmobranchs. In: Hamlett WC (ed) Reproductive biology and phylogeny of Chondrichthyes: sharks, batoids, and chimaeras. Science Publishers, Enfield, p 1-25 
Pardini AT, Jones CS, Noble LR, Kreiser B, Malcolm H, Bruce BD, and others (2001) Sex-biased dispersal of great white sharks. Nature 412:139-140

Peverell SC (2005) Distribution of sawfishes (Pristidae) in the Queensland Gulf of Carpentaria, Australia, with notes on sawfish ecology. Environ Biol Fishes 73:391-402

Phillips NM, Chaplin JA, Morgan DL, Peverell SC (2011) Population genetic structure and genetic diversity of three critically endangered Pristis sawfishes in Australian waters. Mar Biol 158:903-915

Phillips NM, Chaplin JA, Peverell SC, Morgan DL (2016) Contrasting population structures of three Pristis sawfishes with different patterns of habitat use. Mar Freshw Res 68:452-460

Phillips NM, Fearing A, Morgan DL (2017) Genetic bottlenecks in Pristis sawfishes in northern Australian waters. Endang Species Res 32:363-372

Portnoy DS, McDowell JR, Heist EJ, Musick JA, Graves JE (2010) World phylogeography and male-mediated gene flow in the sandbar shark, Carcharhinus plumbeus. Mol Ecol 19:1994-2010

Portnoy DS, Puritz JB, Hollenbeck CM, Gelsleichter J, Chapman D, Gold JR (2015) Selection and sex-biased dispersal in a coastal shark: the influence of philopatry on adaptive variation. Mol Ecol 24:5877-5885

Pusey AE (1987) Sex-biased dispersal and inbreeding avoidance in birds and mammals. Trends Ecol Evol 2:295-299

Rousset F (2008) Genepop'007: a complete re-implementation of the genepop software for Windows and Linux. Mol Ecol Resour 8:103-106

Rozas J, Ferrer-Mata A, Sanchez-DelBarrio JC, Guirao-Rico S, Librado P, Ramos-Onsins SE, Sanchez-Gracia A (2017) DnaSP v6: DNA sequence polymorphism analysis of large datasets. Mol Biol Evol 34:3299-3302

Ryman N, Palm S (2006) POWSIM: a computer program

Editorial responsibility: Dean Grubbs (Guest Editor), St. Teresa, Florida, USA for assessing statistical power when testing for genetic differentiation. Mol Ecol Notes 6:600-602

Seitz JC, Poulakis GR (2006) Anthropogenic effects on the smalltooth sawfish (Pristis pectinata) in the United States. Mar Pollut Bull 52:1533-1540

Simpfendorfer CA (2000) Predicting population recovery rates for endangered western Atlantic sawfishes using demographic analysis. Environ Biol Fishes 58:371-377

* Simpfendorfer CA (2013) Pristis zijsron. The IUCN Red List of Threatened Species. http://dx.doi.org/10.2305/IUCN. UK.2013-1.RLTS.T39393A18620401.en

* Simpfendorfer CA, Kyne PM, Noble TH, Goldsbury J and others (2016) Environmental DNA detects Critically Endangered largetooth sawfish in the wild. Endang Species Res 30:109-116

Slatkin M (1987) Gene flow and the geographic structure of natural populations. Science 236:787-792

Sunnucks P, Hales DF (1996) Numerous transposed sequences of mitochondrial cytochrome oxidase I-II in aphids of the genus Sitobion (Hemiptera: Aphididae). Mol Biol Evol 13:510-524

* Thomson KS, Simanek DE (1977) Body form and locomotion in sharks. Am Zool 17:343-354

Thorburn DC, Morgan DL, Rowland AJ, Gill HS (2007) Freshwater sawfish Pristis microdon Latham, 1794 (Chondrichthyes: Pristidae) in the Kimberley region of Western Australia. Zootaxa 1471:27-41

Tobin AJ, Mapleston A, Harry AV, Espinoza M (2014) Big fish in shallow water; use of an intertidal surf-zone habitat by large-bodied teleosts and elasmobranchs in tropical northern Australia. Environ Biol Fishes 97:821-838

*White WT, Appleyard SA, Kyne PM, Mana RR (2017) Sawfishes in Papua New Guinea: a preliminary investigation into their status and level of exploitation. Endang Species Res 32:277-291

Submitted: September 1, 2016; Accepted: June 22, 2018

Proofs received from author(s): August 20, 2018 